\title{
O QUINTETO DA RENASCENÇA AMERICANA NO BRASIL
}

\author{
Denise Bottmann* \\ Historiadora e tradutora
}

\begin{abstract}
Resumo: Este levantamento abrange uma ampla bibliografia das obras dos cinco autores que formaram a chamada "Renascença americana", traduzidas e publicadas em livro no Brasil até o momento. Seu objetivo é fornecer uma base de dados para pesquisadores da área, servindo como compilação consolidada de informações primárias até então dispersas em várias fontes.

Palavras-chave: Renascença americana. Tradução. História da tradução no Brasil.
\end{abstract}

\section{THE AMERICAN RENAISSANCE QUINTET IN BRAZIL}

\begin{abstract}
This survey provides extensive bibliographical data on the works by the five authors who shaped the so-called American Renaissance, which have been translated into Portuguese and published as book in Brazil until the present day. It has as its purpose to be useful as a sort of archive for ulterior researchers, who will be able to find here many primary data which were until now scattered among several sources.
\end{abstract}

Keywords: American Renaissance. Translation. History of translation in Brazil.

\footnotetext{
* Denise Bottmann fez graduação em História na UFPR e mestrado em Teoria da História na UNICAMP. Foi docente do Departamento de Filosofia da UNICAMP, na área de Epistemologia das Ciências Humanas, entre 1983 e 1996. Dedica-se à atividade de tradução desde 1984 e desde 2008 tem se dedicado a estudos da história da tradução no Brasil. Curitiba, Paraná, Brasil. E-mail: dbottmann@gmail.com
} 
Em seu célebre estudo de 1941, American Renaissance: Art and Expression in the Age of Emerson and Whitman, o estudioso e crítico Francis Otto Matthiessen apresentou cinco autores cujas obras - que viriam a se tornar canônicas dentro do pensamento e da literatura estadunidense - formavam o que ele denominou de "Renascença americana". Além de um veio transcendentalista ou romântico comum a todas elas, havia a curiosa concentração cronológica de suas primeiras edições: o quinquênio compreendido entre 1850 e 1855 . Essa singular constelação abrangia Ralph Waldo Emerson com Representative Men (1850), Nathaniel Hawthorne com The Scarlet Letter (1850) e The House of Seven Gables (1851), Herman Melville com Moby Dick (1851), Henry David Thoreau com Walden (1854) e Walt Whitman com Leaves of Grass (1855).

No Brasil, até onde sei, a acolhida desse conjunto de autores e obras jamais se deu sob a égide da "Renascença americana" - mesmo porque alguns foram traduzidos e publicados entre nós antes da obra de Matthiessen. De todo modo, parece-me um bom mote para ordenar a reconstituição histórico-bibliográfica da presença dos cinco autores entre nós.

Assim, apresento a seguir o levantamento de suas traduções publicadas em livro no Brasil, arroladas pela data de sua primeira edição. Quanto à grande quantidade de poemas, contos e excertos que se encontra dispersa entre várias revistas e suplementos literários de jornais, apenas num ou noutro caso mencionarei algumas ocorrências, a título de curiosidade. Por fim, cumpre notar que uma especial dificuldade nesse tipo de levantamento é conseguir rastrear a totalidade de contos avulsos publicados em antologias de diversos autores: assim, certamente haverá lacunas sob este aspecto, que espero venham a ser preenchidas por outras pesquisas.

\section{Ralph Waldo Emerson (1803-1882)}

O mestre do transcendentalismo americano chegou ao Brasil com a obra que, precisamente, Matthiessen aponta como marco 
inicial da Renascença americana: as sete palestras que Emerson apresentou entre 1845 e 1847, que saíram em livro em 1850 enfeixadas sob o título de Representative Men. Esse volume surgiu inicialmente entre nós com o nome de Os super-homens. Foi lançado pela Cultura Moderna, efêmera editora paulista (1934-1938) criada pelo jornalista, escritor e tradutor Galeão Coutinho, numa edição sem data, que calculo por volta de 1936. Consta na página de rosto que se trata de uma tradução revista por A. Roitman, sem citar o tradutor. Como em 1913 saíra em Portugal a tradução de Domingos Guimarães com o mesmo peculiar título de Os super-homens, eu não excluiria a possibilidade de que tenha sido ela a ser revista e publicada pela Cultura Moderna.

Em 1938, uma pequena editora carioca chamada Multum in Parvo publica Trechos de Emerson, com seleção de Robert James Botkin, em sua Coleção Portátil, v. 4. Não há créditos de tradução.

Em 1940, a Livraria Martins, de São Paulo, publica em sua coleção Pensamento Vivo o volume de excertos organizado por Edgar Lee Masters, O pensamento vivo de Emerson, em tradução de Ida Goldstein.

Ainda em 1940, a Edições e Publicações Brasil Editora, também de São Paulo, publica $A$ conduta da vida, em tradução de C. M. Fonseca. Em 2003, essa tradução foi retomada pela editora paulista Martin Claret, com o título de $A$ conduta para a vida.

Em 1941, a mesma Brasil Editora lança Homens representativos da humanidade, também em tradução anônima revista, agora por Alfredo Gomes, responsável pelo prefácio e notas. Em sua segunda edição (1960), a Brasil substituiu o título pelo mais simples e direto Homens representativos. Nesse mesmo ano de 1960, a editora paulista Edigraf também lança Homens representativos, com tradução agora atribuída diretamente a Alfredo Gomes; e com tal atribuição transfere-se em 1967 para o catálogo da Tecnoprint (futura Ediouro). ${ }^{1}$

Em 1948, a Livraria Editora Progresso, de Salvador, publica English Traits com o título de Inglaterra e sua gente, em tradução de Acácio França. 
Em 1953, temos o ensaio "Caráter", presente na coletânea Ensaístas americanos, em tradução de Sarmento de Beires e José Duarte, pela W. M. Jackson, do Rio de Janeiro, em sua coleção Clássicos Jackson, vol. XXXIII. Ainda que Sarmento de Beires fosse português, exilara-se no Brasil desde 1928, após a implantação da ditadura em Portugal, retornando ao país de origem apenas após a Revolução dos Cravos, em 1974. Por esta razão, julgo legítimo considerá-la uma tradução brasileira de direito próprio. Será indevidamente apropriada pela editora Martin Claret em 2001, num volume chamado Ensaios, copiada na íntegra e atribuída a um ser de ficção de nome "Jean Melville".

Em 1955, a soteropolitana Progresso lança outro volume com o título de Os super-homens, sem qualquer indicação sobre a tradução. Parece-me muito provável que se trate da tradução portuguesa de Domingos Guimarães ou da tradução revista da Cultura Moderna, já comentadas mais acima. Tal hipótese, porém, demanda comprovação.

Em 1961, temos um volume de Ensaios, com seleção, nota introdutória e tradução de José Paulo Paes, pela paulista Cultrix, em sua coleção Clássicos Cultrix, contendo "O Letrado Norte-Americano", "A Confiança em si Próprio", "Compensação", "Amizade", "A Supra-Alma”, "O Poeta", "A Natureza" e "Política".

Em 1994, sai outro volume de Ensaios, correspondendo à coletânea original de Essays (First Series), em tradução de Carlos Graieb e José Marcos Mariani de Macedo, pela editora Imago, do Rio de Janeiro. É a este volume que a editora Martin Claret recorrerá para os demais ensaios de sua edição espúria de 2001, em nome de "Jean Melville", em cópia adulterada e bastante atamancada.

Em 1996, também pela Imago, em sua coleção Lazúli, sai uma nova tradução de Homens representativos: sete conferências, agora de Sônia Régis.

Em 2001, tem-se o volume Ensaios na edição espúria da editora Martin Claret, já citada, em nome de "Jean Melville".

Em 2004, sai uma inacreditável mixórdia de excertos de vários autores, inclusive de Emerson, num volume de autoajuda chama- 
do Inspirações positivas: a chave do sucesso, com organização de Adriana Toledo de Almeida, pela editora paulista Vergara \& Riba.

Em 2010, a L\&PM, de Porto Alegre, publica em apêndice a Walden, de Henry D. Thoreau, o necrológio de Emerson a ele, com o título "Thoreau", em tradução minha.

Em 2011, a editora Dracaena, de Içara, SC, publica Natureza, em tradução de Davi Araújo.

Para 2015, está previsto o lançamento de dois ensaios, "Independência” e “Amizade”, pela L\&PM, em tradução minha.

\section{Nathaniel Hawthorne (1804-1864)}

Outro expoente da Renascença americana é Nathaniel Hawthorne, a quem aliás Herman Melville dedicou seu Moby Dick. Estilista fino, na linha do romantismo sombrio, de extensa obra, é tido como um dos pais da short story americana. Mas, entre nós, Hawthorne é mais conhecido por seus romances The Scarlet Letter, The House of the Seven Gables e The Marble Faun (cujo personagem, aliás, vem inspirado em outro expoente da Renascença americana, Henry D. Thoreau). Além desses três romances, temos no Brasil, dentre sua vasta obra, apenas os mitos gregos adaptados em Tanglewood Tales e A Wonder-Book for Girls and Boys, uma dúzia e meia de contos e só.

Hawthorne chega ao Brasil em 1942, com dois de seus romances: A letra escarlate, em tradução de Sodré Viana, pela José Olympio, em sua coleção Fogos Cruzados, vol. 6; A casa das sete torres, em tradução de Ligia Autran Rodrigues Pereira, pela paulista Livraria Martins em sua Coleção Excelsior, vol. 8. Não sei a qual desses dois lançamentos cabe a anterioridade.

A letra escarlate é, de longe, sua obra mais traduzida entre nós, com nada menos que seis traduções. Além da de Sodré Viana, temos as de Isaac Mielnik, pelo paulista Clube do Livro (1949); A. Pinto de Carvalho, pela paulista Saraiva (1957) e pela Ediouro; Elaine Farhat Sírio, pelo paulista Círculo do Livro (1993); Christian Schwartz, pela paulista Penguin/Companhia, 2011; Gui- 
lherme Braga, pela carioca BestBolso (2012). O romance conheceu também diversas adaptações e quadrinizações.

Quanto a The House of the Seven Gables, a tradução de Lígia Autran pela Martins foi reeditada pelo Clube do Livro (1950), Círculo do Livro (1982-1986) e Abril Cultural (1983). Em c. 1974, a Ediouro (então Edições de Ouro) lançou nova tradução, agora de David Jardim Jr., que saiu em algumas coleções da casa (Clássicos de Bolso, Universidade de Bolso).

Encontrei referências sobre mais uma tradução desse romance, feita também por Sodré Viana, pela José Olympio, com o nome de A casa dos sete oitões, mas não localizei a data de edição. Aliás, a propósito do tradutor Sodré Viana, Englekirk (1948: 355) menciona outras duas obras de Hawthorne que teriam sido traduzidas por ele, também para a José Olympio: The Blithedale Romance (com o título de $O$ romance do Vale Feliz) e The Faun of Marble (O fauno de mármore), sem ano de edição. Porém não localizei nenhuma referência adicional que corroborasse a indicação de Englekirk; fica aqui apenas a menção a ela.

Além dessa menção a uma tradução de The Faun of Marble por Sodré Viana, o suplemento literário dominical Letras e Artes, do diário carioca Correio da Manhã, anunciara numa nota de 21 de maio de 1950 que a editora A Noite programava lançar uma tradução de Avelino Aguiar de $O$ fauno de mármore; em 11 de novembro de 1951, o mesmo suplemento anunciou a iminente publicação da obra pel'A Noite, em sua coleção Stendhal. Até onde sei, esse lançamento anunciado nunca se concretizou. Em 1952, a editora O Cruzeiro, também do Rio de Janeiro, publicou a tradução de Constantino Paleólogo, que nos anos 60 se transferiu para o catálogo da Tecnoprint, em circulação até a data de hoje. Em período mais recente, em 1992, a Nova Fronteira publicou uma nova tradução, agora de Sônia Régis.

Passando a seus contos apanhados em livro, temos Contos da Grécia Antiga, em tradução de Oscar Mendes, pela paulista Melhoramentos, em 1950. No mesmo ano, pela carioca Vecchi, sai $O$ paraíso juvenil, em tradução de Manuel R. da Silva. 
Em 1964, a Cultrix lança Histórias de Nathaniel Hawthorne. Essa bela antologia montada pela fina tradutora que era Olívia Krähenbühl traz: "O paladino grisalho", "O véu negro do ministro", "Os retratos proféticos", "O experimento do dr. Heidegger", "O sinal de nascença", "A estrada de ferro celestial", "Cabeça-de-pena: uma lenda moral", "O egoísmo ou a serpente no peito", "Drowne e sua imagem de madeira", "O grande rosto de pedra" e "Ethan Brand". Foi reeditada, pela própria Cultrix, pela Ediouro e Círculo do Livro, com os títulos de Contos, Os mais brilhantes contos de Nathaniel Hawthorne e Os melhores contos de Nathaniel Hawthorne.

Em 1967, a Tecnoprint publicou três pequenos volumes de lendas da mitologia grega, com adaptação de Orígenes Lessa, baseadas em Hawthorne: A cabeça de Medusa e outras lendas gregas; $O$ Minotauro e outras lendas gregas; $O$ Palácio de Circe e outras lendas gregas. Não excluo a possibilidade de que Orígenes Lessa, para suas adaptações, tenha se baseado na tradução de Oscar Mendes, pela Melhoramentos, citada mais acima.

Em 2001, sai Um livro de maravilhas para meninas e meninos ( $A$ Wonder-Book for Girls and Boys), com tradução de Monica Veronezi Rizzolo e Afonso Teixeira Filho, pela Landy, de São Paulo.

Outra adaptação de $O$ minotauro saiu em 2005, a cargo de Edmir Perrotti, pela editora Paulinas, também de São Paulo.

De mais difícil rastreamento são as antologias de autores variados que incluem algum conto de Hawthorne. Seguem-se as que localizei.

"A experiência do dr. Heidegger", in Os mais belos contos humorísticos, satíricos e jocosos dos mais famosos autores, trad. Manuel R. da Silva. Rio de Janeiro: Vecchi, 1944 (2 ${ }^{\mathrm{a}}$. ed.)

"O herói misterioso" in Os norte-americanos. Antigos e modernos, trad. Afonso Arinos de Melo Franco. Rio de Janeiro: Companhia Leitura, 1945. (Atualmente na carioca Ediouro, com o título Contos norte-americanos: os clássicos.)

"Davi Swan", in Os mais belos contos norte-americanos dos mais famosos autores, trad. J. da Cunha Borges. Rio de Janeiro: Vecchi, 1945. 
Aqui, em 1945-1946, vale notar a publicação de três contos em Letras e Artes, o suplemento dominical do Correio da Manhã, todos em tradução de Wilson Lousada: "A experiência do dr. Heidegger" (em 30/9/45), "O dobre nupcial” (em 10/2/46) e "O hóspede ambicioso" (24/2/46).

"O homem que morreu três vezes", in Os mais belos contos policiais dos mais famosos autores, trad. Alfredo Ferreira [et al.]. Rio de Janeiro: Vecchi, 1947.

"A consoada do quacre", in Livro de Natal: As mais lindas histórias de Natal

dos maiores escritores do mundo, org. Araújo Nabuco, sem créditos de tradução. São Paulo: Livraria Martins, 1947. (Não me surpreenderia se fosse uma tradução portuguesa.)

"A experiência do dr. Heidegger", in Contos norte-americanos, coleção Primores do Conto Universal, vol. 3, org. Jacob Penteado, sem créditos de tradução. São Paulo: Edigraf, 1950.

"Davi Swan", in Mar de Histórias: 1800 a 1860, vol. 2, organização e tradução de Aurélio Buarque de Hollanda e Paulo Rónai. Rio de Janeiro: José Olympio, 1951. Relançado com Contos norte-americanos pela Edições de Ouro (c. 1974).

"David Swan", in Maravilhas do conto norte-americano, sem créditos de tradução. São Paulo: Cultrix, $1957 .^{2}$

"O palácio de Circe", in Titãs da literatura, trad. A. Barbosa Rocha. Rio de Janeiro/São Paulo: El Ateneo, 1958.

Por incrível que pareça, não consegui descobrir qual é o conto de Hawthorne incluído em Os mais belos contos norte-americanos, trad. Therson Santos. Rio de Janeiro: Caravela, 1961.

"A filha de Rappaccini", in Novelas norte-americanas, trad. Eurico Dowens. São Paulo: Cultrix, 1963.

"O jovem mestre Brown", in As melhores histórias insólitas, trad. Alair de Oliveira Gomes. Rio de Janeiro: Bruguera, s/d (c.1972).

"A filha de Rappaccini", in $O$ melhor da ficção científica do século XIX, trad. Barbara Theoto Lambert. São Paulo: Melhoramentos, 1988. 
"Meu parente, o major Molineux", in América, Clássicos do conto norte-americano, trad. Celso M. Paciornik. São Paulo: Iluminuras, 2001.

"O hóspede ambicioso", in $A$ selva do dinheiro, trad. Roberto Muggiati. Rio de Janeiro: Record, 2002.

Toque de ouro, trad. Tatiana Belinky. São Paulo: Editora 34, 2002.

"Wakefield" e "Penacho, o espantalho", in Contos e poemas para crianças extremamente inteligentes de todas as idades, vol. 3, trad. José Antônio Arantes. Rio de Janeiro: Objetiva, 2003.

"O jovem Goodman Brown", in Contos fantásticos do século $X I X$, org. Italo Calvino, trad. Ricardo Lísias. São Paulo: Companhia das Letras, 2004.

"O banquete de Natal", in Os mais belos contos de amor e esperança, trad. Chico Lopes. Rio de Janeiro: Prestígio, 2005.

"Wakefield", in Contos fantásticos no labirinto de Borges, org. Bráulio Tavares, trad. Cristiana Serra. Rio de Janeiro: Casa da Palavra, 2005.

"O experimento do dr. Heidegger", in Os melhores contos de medo, horror e morte, org. Flávio Moreira da Costa, trad. Rubem Mauro Machado. Rio de Janeiro: Nova Fronteira, 2005.

"O paladino encanecido", in Os melhores contos que a história escreveu, org. Flávio Moreira da Costa, trad. Celina Portocarrero. Rio de Janeiro: Nova Fronteira, 2005.

Vinte dias com Julian \& Coelhinho, por papai, Sônia Coutinho, José Olympio, 2006

"O jovem Goodman Brown", in Os melhores contos fantásticos, org. Flávio Moreira da Costa, trad. Maria Luiza X. de A. Borges. Rio de Janeiro: Nova Fronteira, 2006.

"A marca de nascença", in Contos de amor do século XIX, org. Alberto Manguel, trad. Bernardo Carvalho, Companhia das Letras, 2007.

Os contos de Hawthorne mais traduzidos entre nós são, portanto, "The experiment of Dr. Heidegger", "David Swan" e "Young Goodman Brown". "Wakefield" se soma a eles, se incluirmos al- 
gumas traduções disponíveis online, como a de Silveira de Souza na Virtualbooks e a de Zaida Maldonado na revista literária virtual Bestiário, I.5, 2004.

\section{Herman Melville (1819-1891)}

Passemos agora a Herman Melville, a terceira estrela da constelação da chamada American Renaissance traduzida no Brasil.

Comecemos pelo magnum opus de Melville, Moby Dick, que, como já dissemos, traz dedicatória a outro expoente da Renascença Americana, Nathaniel Hawthorne. Dispomos no Brasil de quatro traduções integrais, além de duas espúrias, bem como de uma infinidade de adaptações e quadrinizações. ${ }^{3}$

Antes de enumerarmos as traduções integrais, gostaria de destacar uma adaptação de Moby Dick, que foi precisamente a edição que introduziu Melville no Brasil, em tradução e adaptação de Monteiro Lobato e Adalberto Rochsteiner, com o subtítulo de $A$ fera do mar. Saiu em 1935, pela Companhia Editora Nacional, de São Paulo, e continua em circulação até hoje. Será sempre difícil exagerar o papel de Monteiro Lobato em trazer a nós diversos autores importantes, até então inéditos no Brasil.

Passando às traduções integrais, a primeira a ser lançada foi a de Berenice Xavier, em 1950, pela José Olympio, em sua coleção Fogos Cruzados. ${ }^{4}$ Foi relançada pela Francisco Alves (1982), Biblioteca Folha (1998) e Abril Coleções (2010).

Em 1972, sai pela Abril Cultural aquele verdadeiro portento que é a tradução de Péricles Eugênio da Silva Ramos.

Em 2008, temos a tradução de Irene Hirsch e Alexandre Barbosa de Souza, pela Cosac Naify, de São Paulo.

Em 2012, a paulista Landmark publica a tradução de Vera Sílvia Camargo Guarnieri.

Quanto às traduções espúrias, a primeira delas saiu pela Martin Claret, em 2004, apropriando-se indevidamente da tradução de Péricles Eugênio da Silva Ramos, procedendo a adulterações grotes- 
cas e atribuindo sua autoria a um fantasmagórico "Alex Marins". Provando de seu próprio veneno, a Martin Claret, por sua vez, em 2005 teve sua atamancada fraude reproduzida por uma pequena editora paulista, agora extinta, a Germape, que utilizou o nome de uma tal "Leonor de Medeiros" como pretensa autora da tradução. Com o encerramento de suas atividades, a Germape transferiu seu pequeno catálogo (contendo outras edições espúrias) à belorizontina Cedic, que, embaída, continuou a publicar a fraude germape-claretiana. Avisada, a Cedic retirou suas edições de circulação.

Isso quanto a Moby Dick.

Vejamos agora as demais obras de Melville traduzidas e publicadas no Brasil.

Em 1945, temos “A história do "Town-ho'” com tradução de Guilherme Figueiredo, integrando a antologia Os norte-americanos: antigos e modernos, organizada por Vinícius de Moraes, na coleção Contos do Mundo, vol. 3, da efêmera editora carioca Leitura. Essa antologia está atualmente no catálogo da Ediouro, com o título de Contos norte-americanos: os clássicos. Essa tradução de "A história do "Town-ho'" foi incluída no volume Contos norte-americanos, lançado pela carioca BUP em 1963, e na coletânea Os melhores contos de aventuras, pela carioca Agir, em 2008.

Em 1952, saem "Benito Cereno" e "Billy Budd" apanhados num volume de título Dramas do mar, em tradução de Octavio Mendes Cajado, pela editora paulista Saraiva. Será reeditado várias vezes pela Tecnoprint a partir de 1966.

Em 1961, sai o primeiro "Bartleby" brasileiro em Os mais belos contos norte-americanos, em tradução de Therson Santos, pela editora Caravela, do Rio de Janeiro.

Em 1963, temos "Billy Budd, gajeiro do mastro real" em tradução de Eurico Dowens, na coletânea Novelas norte-americanas, com seleção de Cassiano Nunes, pela Cultrix.

Em 1967, Bartleby sai com o título de "Prefiro não fazer - uma história de Wall Street”, na coletânea Sete novelas clássicas, em tradução de Márcio Cotrim, numa coedição Imago/ Lidador. 
Ainda em 1967, o Clube do Livro lança uma "tradução especial" de Omoo, A Narrative of Adventures in the South Seas, com o título de Mares do Sul, atribuindo-a a Jacob Penteado e a José Maria Machado. Em vista do histórico das "traduções especiais" do Clube do Livro, que mereceriam um artigo à parte, fica difícil garantir a integridade dessa edição.

Em 1969, temos pela Cultrix a coletânea selecionada e traduzida por Olívia Krähenbühl, com o título de Contos de Herman Melville: "Bartleby", "O homem do para-raios", "O terraço" e "Benito Cereno" (que integravam The Piazza Tales, de 1856). De 1987 em diante, sai pelo Círculo do Livro com o título de Os melhores contos de Herman Melville.

Em c.1971, Billy Budd sai em sua terceira tradução, agora de Pedro Porto Carreiro Ramires, pela carioca Bruguera.

Também em c. 1971, temos um terceiro Benito Cereno, em tradução de Sandro Pivatto, também pela Bruguera.

Em1982, sai a quarta tradução de Bartleby, o escrivão, esta de A. B. Pinheiro de Lemos, pela Record, e agora na José Olympio, atualmente integrante do Grupo Record.

Em 1984, temos Taipi, paraíso de canibais, em tradução de Henrique Araújo Mesquita, pela L\&PM.

Em 1986, aparece um quinto Bartleby, agora o escriturário, em tradução de Luís de Lima, pela Rocco do Rio de Janeiro.

Em 1992, vem mais um Benito Cereno, agora em tradução de Daniel Piza, pela Imago.

Ainda em 1992, mais um pouco de novidade: $O$ vigarista - seus truques, em tradução de Eliana Sabino, pela paulista 34.

Em 2003, retorna o incansável Bartleby, o escriturário: uma história de Wall Street, em tradução de Cássia Zanon, pela L\&PM.

No mesmo ano, temos a quarta tradução de Billy Budd, agora por Alexandre Hubner, pela Cosac Naify.

Em 2005, mais um Billy Budd, marinheiro, agora em tradução de Cássia Zanon, pela L\&PM.

Em 2006, sai o sétimo Bartleby, o escrivão - uma história de Wall Street, em tradução de Irene Hirsch, pela Cosac Naify. 
Em 2009, mais um pouco de novidade, com o ensaio Hawthorne e seus musgos, em tradução de Luiz Roberto Takayama, pela paulista Hedra.

Em 2011, continuam algumas novidades com $O$ violonista $e$ outras histórias, em tradução de Lúcia Helena de Seixas Brito, pela curitibana Arte e Letra, com o conto que dá título ao volume, mais "O homem do para-raios", "Eu e minha chaminé", "A varanda", "O paraíso dos solteirões" e "O inferno das donzelas".

Em 2014, o infatigável Bartleby retorna, desta vez em tradução de Bruno Gambarotto, pela editora Grua Livros, em sua coleção A Arte do Conto.

Resumindo: o campeão de traduções é Bartleby, com nada menos de oito entre 1961 e 2014; segue-se Billy Budd com cinco, entre 1952 e 2005; depois, Benito Cereno com quatro traduções entre 1952 e 1992. "O terraço"/ "A varanda" e "O homem do para-raios", que também fazem parte das Piazza Tales ao lado de "Bartleby" e "Benito", ganharam duas traduções. Cabe notar que os outros dois contos que completam a coletânea original, "The Encantadas or Enchanted Isles" e "The Bell-Tower", pelo visto continuam inéditos entre nós. Por outro lado, algumas editoras contribuem com um pouco de salutar variedade, inclusive pelo lado ensaístico de Melville. Já pretender que lancem a tradução de algum poema talvez seja querer demais.

\section{Henry David Thoreau (1817-1862)}

Os textos de Henry David Thoreau traduzidos no Brasil são os seguintes, por ordem alfabética dos títulos em português: ${ }^{5}$

1. “A escravidão em Massachusetts" - traduções de José Augusto Drummond, José Geraldo Couto.

2. "A vida sem princípio" - traduções de E. C. Caldas, José Paulo Paes, José Augusto Drummond, José Luiz Perota, José Geraldo Couto. 
3. "Andar a pé" (também como "A arte de caminhar", "Caminhada", "Caminhando", "O pequeno livro da sabedoria", novamente "Caminhando", novamente "Caminhada") - traduções respectivas de Sarmento de Beires e José Duarte, E. C. Caldas, Aydano Arruda, José Augusto Drummond, Vera Renoldi, Roberto Muggiati, Davi Araújo, José Geraldo Couto.

4. "Cartas familiares selecionadas" - tradução de Aydano Arruda.

5. "Desobediência civil" (ou "Resistência ao governo civil") - traduções de E. C. Caldas, Aydano Arruda, José Paulo Paes, David Jardim Jr., José Augusto Drummond, Astrid Cabral, Sergio Karam, José Geraldo Couto.

6. "Domingo" (segundo dia de $A$ Week on the Concord and Merrimack Rivers) - tradução de Aydano Arruda.

7. "O naufrágio" (primeiro capítulo de Cape Cod) - tradução de Aydano Arruda.

8. "Onde vivi e a razão por que vivi" (segundo capítulo de Walden) - traduções de Aydano Arruda, José Geraldo Couto.

9. “Os lagos Allegash" (terceira parte de The Maine Woods) tradução de E. C. Caldas.

10. "Paraíso (a ser) recobrado" - tradução de José Paulo Paes.

11. "Três excertos de $A$ Week on the Concord e Merrimack Rivers" - tradução de José Augusto Drummond.

12. "Um apelo em prol do Capitão John Brown" - tradução de José Paulo Paes.

13. Excertos variados em seleção de Theodore Dreiser - tradução de Lauro Escorel.

14. Walden - traduções de E. C. Caldas, Astrid Cabral, Denise Bottmann.

As referências bibliográficas, dispostas em ordem cronológica da primeira edição no Brasil, são: 
1. O pensamento vivo de Thoreau. Coleção Biblioteca do Pensamento Vivo. Seleção, organização e introdução de Theodore Dreiser. Tradução de Lauro Escorel. Contém excertos variados. São Paulo: Livraria Martins, 1939. 181 p.

2. Ensaístas americanos. Coleção Clássicos Jackson, vol. XXXIII. Tradução de Sarmento de Beires e José Duarte. Contém "Andar a pé”. Rio de Janeiro: W. M. Jackson, 1950. $360 \mathrm{p}$.

3. Walden e outros escritos. 2 volumes. Introdução de Brooks Atkinson. Tradução de E. C. Caldas. Contém Walden, "Os lagos Allegash", "A arte de caminhar", "Desobediência civil", "Vida sem princípio". Rio de Janeiro: Revista Branca, 1953. $184 \mathrm{p}$.

4. Escritos selecionados sobre natureza e liberdade. Série Clássicos da Democracia, vol. 25. Tradução de Aydano Arruda. Contém: "Desobediência Civil", "Onde vivi e a razão por que vivi”, "Naufrágio", "Domingo", "Caminhada”, “Cartas familiares selecionadas”. São Paulo: IBRASA, 1964. $167 \mathrm{p}$.

5. A desobediência civil e outros ensaios. Seleção, introdução, tradução e notas de José Paulo Paes. Contém: “A desobediência civil", “A vida sem princípio", "Paraíso (a ser) recobrado", "Um apelo em prol do Capitão John Brown". São Paulo: Cultrix, 1968. 130 p.

6. Walden. Introdução de Brooks Atkinson. Tradução de E. C. Caldas. Rio de Janeiro: Edições de Ouro, 1968. 350 p.

7. Desobedecendo. A desobediência civil \& outros escritos. Apresentação de Fernando Gabeira. Seleção, introdução, tradução e notas de José Augusto Drummond. Contém: “A desobediência civil”, "A vida sem princípio", "Caminhando", "A escravidão em Massachusetts" e trechos escolhidos de Uma semana nos rios Concord e Merrimack. Rio de Janeiro: Rocco, 1984. $167 \mathrm{p}$.

8. Walden, ou a vida nos bosques. Coleção Armazém do Tempo. Introdução e tradução de Astrid Cabral. Contém em 
apêndice "A desobediência civil”. São Paulo: Global, 1986. 331 p.; Aquariana, 2001 (346 p.); Novo Século, 2007 (288 p.).

9. Desobediência civil (Resistência ao governo civil) e Walden. Coleção Universidade de Bolso. Introdução de Brooks Atkinson. Traduções respectivas de David Jardim Jr. e E. C. Caldas. Rio de Janeiro: Ediouro, c. 1987. 217 p.

10. O pequeno livro da sabedoria. Tradução de Vera Maria Renoldi. São Paulo: BestSeller (C.L.C.), 1996; Rio de Janeiro: BestSeller (Record), 2005. 81 p.

11. A desobediência civil. Coleção L\&PM Pocket. Tradução de Sergio Karam. Porto Alegre: L\&PM, 1997. 80 p.

12. Caminhando. Coleção Sabor Literário. Introdução e tradução de Roberto Muggiati. Rio de Janeiro: José Olympio, 2006. 126 p.

13. Walden. Coleção L\&PM Pocket. Apresentação de Eduardo Bueno. Tradução de Denise Bottmann. Contém em apêndice "Thoreau", necrológio de Ralph Waldo Emerson. Porto Alegre: L\&PM, 2010. 335 p.

14. Caminhada. Tradução de Davi Araújo. Içara: Dracaena. $56 \mathrm{p}$.

15. Vida sem princípio. Tradução de José Luiz Perota. Içara: Dracaena, 2011. 48 p.

16. A desobediência civil. Tradução de José Geraldo Couto. Contém "A desobediência civil", "Onde vivi, e para quê", "A escravidão em Massachusetts", "Caminhar", "Vida sem princípios”. São Paulo: Penguin/ Companhia, 2012. 152 p.

De longe os ensaios de Thoreau mais traduzidos no Brasil são Walking e Civil Disobedience, com oito traduções cada (sem contar as espúrias). ${ }^{6}$ Por outro lado, coisas fundamentais como $A$ Week on the Concord and Merrimack Rivers continuam inéditas. 


\section{Walt Whitman (1819-1892)}

A grande voz oceânica de Walt Whitman, na feliz expressão de Ivo Barroso, aparece em livro no Brasil em 1942, dentro do projeto americanista do BIPA (Bureau de Informaciones Pan-americano, com seu escritório brasileiro sediado no Rio de Janeiro). Com o Editorial Novo Continente, publica uma antologia de Poetas norte-americanos organizada pelo uruguaio Gastón Figueira, trazendo "Vejo uma imensa esfera rolando no espaço" na tradução de Octavio Azevedo.

Em iniciativa mais autóctone, data de 1944 ou 1945 aquele que parece ser o primeiro livro dedicado a Whitman entre nós: Saudação ao mundo e outros poemas, em tradução de Mário D. Ferreira Santos, pela editora paulista Flama.

Em 1945, Luís da Câmara Cascudo publica sua tradução de três poemas (I hear America singing, The base of All Metaphysics e For you, o Democracy) no jornal $A$ República de Natal, que posteriormente foram apanhados num fino volume de 15 páginas, com o título de Três poemas de Walt Whitman, lançado pela Imprensa Oficial de Recife, na Coleção Concórdia, em 1957.

Em 1946, a José Olympio lança a tradução de Oswaldino Marques de Cantos de Walt Whitman, em sua coleção Rubaiyat, contendo "Vejo uma imensa esfera rolando no espaço", "Eu ouço a América cantando", "Para ti, ó Democracia”, "Ó capitão! meu capitão!", "Para um malogrado revolucionário europeu”, "Para aquele que foi crucificado", "Quem estará lendo isto agora?", "Uma vez atravessei uma cidade populosa", "Os outros podem elogiar o que quiserem", "Não me fecheis as vossas portas", "Neste instante, saudoso e pensativo", "Para um estranho de cabaré", "Para um estrangeiro".

Em 1955, Oswaldino Marques organiza o volume Videntes $e$ sonâmbulos: Coletânea de poemas norte-americanos, o qual foi reeditado com o título de O livro de ouro da poesia dos Estados Unidos, contendo seis poemas de Whitman: "Transbordante de vida", em tradução de Mário Ferreira Santos; "O fundamento de toda metafísica”, em tradução de Câmara Cascudo; "Quando da última vez 
floresceram os lilases...", em tradução de Emilio Carrero Guerra; "Saudação de Natal”, em tradução de Oswaldino Marques; "Ó estrela de França” e "Adeus”, em tradução de Pompeu de Souza.

Em 1956, temos o volume de poemas Sinfonia da vida, em seleção e tradução de Messias Pereira Donato, sem indicação de editora, relançado em 2011 pela RTM, de Belo Horizonte.

Em c.1960, a editora Logos lança Antologia de poetas estrangeiros, em sua coleção Antologia da Literatura Mundial, vol. 8, com seleção e notas de Afonso Telles Alves, contendo "Saudação de Natal", "Para um estranho", "Para uma prostituta vulgar", "Para ti, ó Democracia" e "Quem estará lendo isto agora", em tradução de Oswaldino Marques. Aparentemente, a mesma edição é lançada pela Edigraf, também em c.1960.

Em 1964, Geir Campos publica pela Civilização Brasileira sua seleção e tradução de excertos de Leaves of Grass, dando-lhe o título de Folhas de relva - o que poderia induzir algum leitor a pensar que seria uma íntegra. O volume é reeditado pela Brasiliense em 1983, com tradução bastante modificada em relação à de 1964, agora com o título de Folhas das Folhas de relva (ecoando as Flores das Flores do mal, a célebre seleta de Guilherme de Almeida para a obra de Baudelaire), e a partir de 1986 pela Ediouro.

Em 1965, sai pela Martins a biografia Walt Whitman por Babette Deutsch, em tradução de Brenno Silveira, com poemas cuja tradução coube a Péricles Eugênio da Silva Ramos ("Canto do Universal", "Ouço o Canto da América").

Em 1976, aparece "A preciosa instituição do amor entre camaradas", em Poetas norte-americanos, antologia bilíngue com organização e tradução de Paulo Vizioli, pela Lidador, como "Edição comemorativa do Bicentenário da Independência dos Estados Unidos da América, 1776-1976".

Em 1988, em Grandes poetas da língua inglesa do século XIX, antologia selecionada e traduzida por José Lino Grünewald, pela Nova Fronteira, saem os poemas "Murmúrios da morte celestial", "Broadway", "A base de toda metafísica", "A ti, ó democracia" e "Uma mulher espera por mim". 
Também em 1988, temos Walt Whitman. A formação do poeta, biografia de Paul Zweig traduzida por Ângela Melim, trazendo poemas e excertos em tradução de Eduardo Francisco Alves, pela carioca Jorge Zahar.

Em 1992, sai "Quando ouvi o astrônomo erudito" na Antologia da nova poesia norte-americana, em seleção e tradução de Jorge Wanderley, pela Civilização Brasileira, em edição bilíngue.

Em 1995, a carioca Objetiva publica $O$ cânone ocidental, de Harold Bloom, em tradução de Marcos Santarrita. O capítulo "Walt Whitman como centro do cânone americano" traz os seguintes poemas completos: Clear Midnight; [In vain were nails driven through my hands] (do caderno pessoal de Whitman, inacabado e inédito); The Last Invocation; [It brings the rest around it] (do caderno pessoal de Whitman, idem). Além disso, aparecem fragmentos dos seguintes poemas: The Sleepers, Songs of Myself, Spontaneous Me, Crossing Brooklyn Ferry, As I ebb'd with the ocean of life e When lilacs last in the dooryard bloom'd.

Vale menção o lançamento do poema "Eu canto o corpo elétrico", em tradução de Ivo Barroso para os Cadernos de Espetáculos 2, setembro de 1996.

Em 2000, temos Song of Myself / Canção de mim mesmo em tradução de André Cardoso, pela Imago/ Alumni, em edição bilíngue.

Em 2001, aparece uma seleção e tradução de Ramsés Ramos para excertos de Folhas da relva, pela Plano/ Oficina Editorial da UnB, Brasília.

Em 2003, em Gênio: os 100 escritores mais criativos da história da literatura, com tradução de José Roberto O'Shea, pela Objetiva, temos os seguintes poemas completos: As Adam Early in the Morning, [In vain were nails driven through my hands] e [Mostly this We Have of Gods]. Além deles, fragmentos de The Wound-Dresser, When lilacs last in the dooryard bloom'd, Spontaneous Me, Song of Myself e As I ebb'd with the ocean of life.

Em 2005, a editora Martin Claret publica Folhas de relva em tradução de Luciano Alves Meira. 
Em 2006, a Iluminuras publica Folhas de relva em tradução de Rodrigo Garcia Lopes, em edição bilíngue, a partir da primeira versão do autor (1855).

Em 2011, sai a edição de Folhas de relva na versão final de 1889, dita "do leito de morte" (que Whitman dera em testamento como a única autorizada), com tradução de Bruno Gambarotto, pela Hedra.

Sem dúvida devem existir vários outros poemas e excertos traduzidos e publicados em antologias e coletâneas impressas, que não cheguei a localizar.

\section{Conclusão}

Eis, pois, a constelação renascentista americana tal como está presente entre nós. Sobre a variada acolhida que tiveram esses autores e seu impacto diversificado entre o mundo da leitura e das letras brasileiras, existem fartos materiais documentais e enorme quantidade de análises e estudos críticos. Fertilíssimo terreno!

\section{Notas}

1. Aqui levanto mais uma hipótese: como a Cultura Moderna encerrou suas atividades em 1938, talvez não seja impossível que sua conterrânea paulista, a Brasil, tenha utilizado a mesma tradução anterior, submetendo-a a nova revisão e dando-lhe um título mais próximo do original. Além disso, creio que caberia um cotejo entre a tradução revista por Alfredo Gomes na Brasil e a supostamente feita por ele para a Edigraf.

2. Entre 1957 e 1958, a Cultrix publicou uma coleção chamada Maravilhas do conto universal, em 24 volumes, coordenada por Edgard Cavalheiro. A maioria 
desses volumes se compunha de contos já publicados por diferentes editoras, tanto em Portugal quanto sobretudo no Brasil, em várias traduções. Alguns volumes das coleções a cargo de Jacob Penteado, na Edigraf, também padeciam do mesmo defeito.

3. Para as dezenas e dezenas de adaptações de Moby Dick no Brasil, veja-se "Aniversário de Moby Dick", http://naogostodeplagio.blogspot.com.br/2011/11/ aniversario-de-moby-dick.html.

4. Aqui vem muito a propósito um precioso esclarecimento de Mário Luiz Frungillo: "Sobre a tradução de Berenice Xavier, uma curiosidade: Na primeira edição, de 1950, faltavam as epígrafes sobre as baleias. A falta foi notada por Augusto Meyer, em artigo sobre o centenário do romance (depois recolhido em Preto \& Branco). Nas edições seguintes a José Olympio reintroduziu as epígrafes, em tradução de Olívia Krähenbühl, e aproveitou também para incluir a 'epígrafe que escapou a Hermann Melville', encontrada por Meyer na Descrição da Ilha de Itaparica, do Frei Manuel de Santa Maria Itaparica”.

5. Encontra-se amplo material sobre o autor em meu blog de trabalho, Lendo Walden, http://lendowalden.blogspot.com.br/.

6. Existe uma edição da Martin Claret indigna de constar em qualquer bibliografia séria, lançada em 2005 com o título de $A$ desobediência civil e outros escritos. Contém: "A desobediência civil"; "Andar a pé"; "Trechos escolhidos" [sic; são trechos de Walden]; "Um passeio num inverno rigoroso"; "Uma semana nos rios Concord e Merrimack" [trechos], com traduções tomadas a Beires/Duarte e Drummond, atribuindo-as ao mesmo fantasmagórico "Alex Marins" que consta na fraudulenta edição de Moby Dick, da mesma editora, comentada mais acima.

AGRADECIMENTOS: Várias pessoas contribuíram generosamente com indicações e referências bibliográficas, bem como informações de conteúdo de diversas obras entre as arroladas acima. Agradeço, entre outros, a Ivo Barroso, Lucas Cordeiro, Ademir Demarchi, Elaphar, Mário Frungillo, Bruno Gambarotto, Fabrizio Lyra, Alfredo Monte, Sérgio Tadeu Guimarães Santos e Mário Zeidler Filho.

As principais fontes para este levantamento foram primárias, com consulta a vários acervos públicos e particulares, entre eles: Fundação Biblioteca Nacional, Hemeroteca Digital da Biblioteca Nacional, Biblioteca Nacional de Portugal e Portal Estante Virtual. 


\section{Referências}

HALLEWELL, Laurence. O livro no Brasil. $2^{\mathrm{a}}$. ed. rev. e ampl. Trad. Maria da Penha Villalobos, Lólio Lourenço de Oliveira e Geraldo Gérson de Souza. São Paulo: EDUSP, 2005.

HIRSCH, Irene. Translations of Herman Melville in Brazil. In: Crop, 6, 2001, p. $129-142$.

ENGLEKIRK, John E. Bibliografia de obras norte-americanas em tradução portuguesa. In: Revista IberoAmericana, XIV, 28, 1948, p. 307-391.

MATTHIESSEN, Francis Otto. American Renaissance: Art and Expression in the Age of Ermerson and Whitman. Londres: Oxford University Press, 1941.

PARO, Maria Clara Bonetti. Walt Whitman in Brazil. In: Walt Whitman Quarterly Review, XI, 2, Fall 1993, p. 57-66.

Recebido em: 02/09/2014 Aceito em: $06 / 12 / 2014$ 